\title{
Evaluation of the spherical near field range at the technical university of Denmark
}

\author{
Lemanczyk, J; Hansen, Jesper; Larsen, Flemming Holm
}

Published in:

Antennas and Propagation Society International Symposium

Publication date:

1984

Document Version

Publisher's PDF, also known as Version of record

Link back to DTU Orbit

Citation (APA):

Lemanczyk, J., Hansen, J., \& Larsen, F. H. (1984). Evaluation of the spherical near field range at the technical university of Denmark. In Antennas and Propagation Society International Symposium (Vol. Volume 22, pp. 682685). IEEE.

\section{General rights}

Copyright and moral rights for the publications made accessible in the public portal are retained by the authors and/or other copyright owners and it is a condition of accessing publications that users recognise and abide by the legal requirements associated with these rights.

- Users may download and print one copy of any publication from the public portal for the purpose of private study or research.

- You may not further distribute the material or use it for any profit-making activity or commercial gain

- You may freely distribute the URL identifying the publication in the public portal

If you believe that this document breaches copyright please contact us providing details, and we will remove access to the work immediately and investigate your claim. 
EVALUATION OF THE SPHERICAL NEAR FIELD RANGE AT TEE TECHNICAL UNIVERSITY OF DENMARK *)

J. Hau Lemanczyk, J.E. Hansen, F. Holm Larsen Electromagnetics Institute, The Technical University of Denmark

Introduction. In order to validate claimed accuracies for antenna measurements on the spherical near field test range at the Technical University of Denmark (TUD), a systematic program of measurements was carried out during which the many parameters in the system were varied and their effects investigated. The antenna was an 34 by 19 wavelength elliptical offset fed reflector producing a shaped beam as seen in figure 1 . The antenna was nominally linearly polarized.

Measurements and parameters. It was wished to ascertain if the various measurement parameters had any effects on the final results of a spherical near field measurement transformed to the far field. The effects were monitored with respect to:

- Gain in a given $(\theta, \phi)$ direction

- Directivity in a given $(\theta, \phi)$ direction

- First sidelobe levels

- Cross polar levels

- Antenna polarization consistency

- Amplitude phase relationship between the two near field receiving channels.

The parameters which were altered systematically to enable the investigations included:

- Scanning speed

- Measurement distance

- Scan type (polar or azimuthal)

- Location of the test antenna in the measurement sphere.

By changing these parameters, it was hoped to see the effects of for example:

- Multiple reflections

- Room effects

- Receiver linearity and noise

- Antenna deformations under scanning

- Mechanical alignment accuracy

- Probe calibration accuracy

Results. The measurement program produced fifty far fields all taken at $12.0000 \mathrm{GHz}$. This provided a sound basis for the accuracies claimed. Typical far field patterns are presented in

*) The present work was carried out under ESA Contract No. 4682 $/ 81 / \mathrm{NL} / \mathrm{MS}$ (SC).

CH2043-8/84/0000-0682\$01.00 (C) 1984 IEEE 
figure 2 which displays far fields from near field measurements at three distances. Results in summary form are shown in the table below:

T A B L E

\begin{tabular}{|c|c|c|c|}
\hline $\begin{array}{l}\text { measured } \\
\text { quantity }\end{array}$ & $\begin{array}{l}\text { direction } \\
(\theta, \phi) \\
\text { degrees }\end{array}$ & value & $\begin{array}{l}\text { one sigma } \\
\text { accuracy }\end{array}$ \\
\hline $\begin{array}{l}\text { directivity } \\
"\end{array}$ & $\begin{array}{r}(5.3,180) \\
(5.1,0)\end{array}$ & $\begin{array}{l}29.89 \mathrm{dBi} \\
29.70 \mathrm{dBi}\end{array}$ & $\begin{array}{l} \pm 0.02 \mathrm{~dB} \\
\pm 0.04 \mathrm{~dB}\end{array}$ \\
\hline $\begin{array}{c}\text { gain } \\
\text { " }\end{array}$ & $\begin{array}{r}(5.3,180) \\
(5.1, \quad 0)\end{array}$ & $\begin{array}{l}29.35 \mathrm{dBi} \\
29.12 \mathrm{dBi}\end{array}$ & $\begin{array}{l} \pm 0.09 \mathrm{~dB} \\
\pm 0.09 \mathrm{~dB}\end{array}$ \\
\hline $\begin{array}{l}\text { sidelobe level } \\
\text { " } \\
"\end{array}$ & $\begin{array}{l}(12.9, \quad 0) \\
(13.1,180) \\
(7.6,90)\end{array}$ & $\begin{array}{l}-31.46 \mathrm{~dB} \\
-34.83 \mathrm{~dB} \\
-20.22 \mathrm{~dB}\end{array}$ & $\begin{array}{l} \pm 0.48 \mathrm{~dB} \\
\pm 0.79 \mathrm{~dB} \\
\pm 0.12 \mathrm{~dB}\end{array}$ \\
\hline $\begin{array}{l}\text { cross polar level } \\
\text { maximum in } \\
\phi=0^{\circ} / 180^{\circ} \text { plane }\end{array}$ & $(3.5,180)$ & $-20.82 \mathrm{~dB}$ & $\pm 0.22 \mathrm{~dB}$ \\
\hline
\end{tabular}

TUD spherical near field test facility accuracies as evaluated from fifty measurements made at $12.0000 \mathrm{GHz}$ on a 34 by 19 wavelength elliptical offset reflector antenna.

As the system at TUD measures two orthogonal field components simultaneously, accurate far field results require knowledge of the amplitude phase relationship between the two measuring ports as well as their polarization characteristics. From the measurements, it was seen that the amplitude ratio could be determined within $\pm 0.07 \mathrm{~dB}$, and the phase between them was determined to within $\pm 0.6^{\circ}$. Probe polarization was determined with an accuracy of $\pm 2 \mathrm{~dB}$ for a $50 \mathrm{~dB}$ axial ratio as well as a tilt angle accuracy of $\pm 0.2^{\circ}$.

Conclusion. The accuracy of the TUD spherical near field test range has been studied through the measurement and subsequent near field to far field transformation of the radiation from an 34 by 19 wavelength elliptical contoured beam antenna.

A series of fifty measurements where single parameters were varied in a systematical manner enabled the one sigma accuracies for directivity, gain, sidelobe level and cross polar maximum at $12.0000 \mathrm{GHz}$ to be determined. 


\section{References}

1. J. Hau Lemanczyk: "Accuracy of spherical near field testing of an MBB contoured beam antenna", Electromagnetics Institute, Technical University of Denmark, Lyngby, Denmark, report R 281, December 1983.

2. F. Holm Larsen, J.H. Lemanczyk, J.E. Hansen: "Antenna calibration at the TUD-ESA spherical near-field range", Antenna Measurement Techniques Association Meeting, 27-29 September 1983, Annapolis, MD, USA.

3. J.E. Hansen: "Spherical near-field testing of spacecraft antennas", ESA Journal, Vol. 14, Pp. 89-102, April 1980.

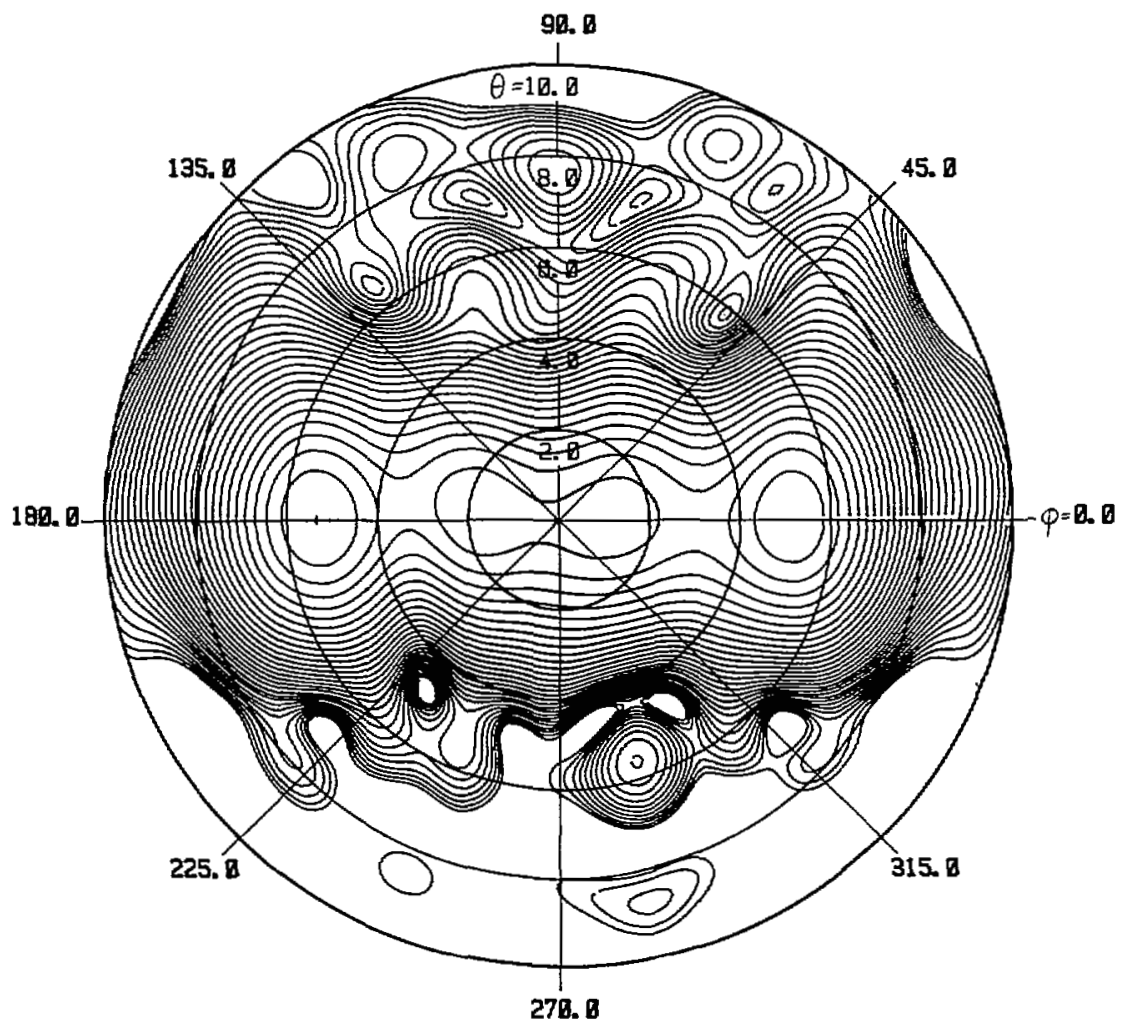

Figure 1. Co polar contour plot in $1 \mathrm{~dB}$ steps for $\theta=0^{\circ}$ to $10^{\circ}$ and $\phi=0^{\circ}$ to $360^{\circ}$. Maximum at $(\theta, \phi)=\left(5.30^{\circ}, 180^{\circ}\right)$. 


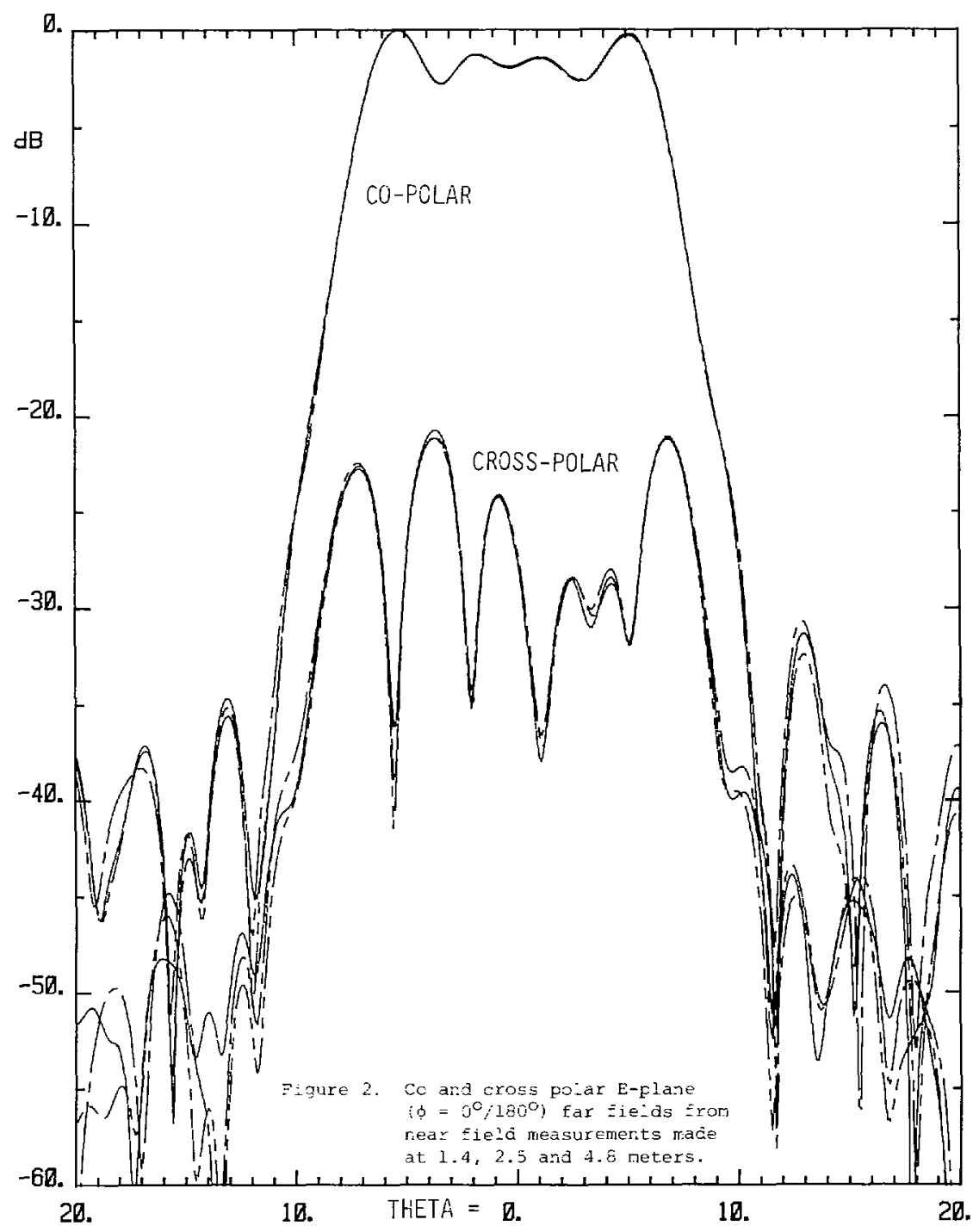

